\title{
Assessment of the efficiency of essential oils in the preservation of postharvest papaya in an antimicrobial packaging system
}

\author{
Avaliação da eficiência de óleos essenciais na preservação pós-colheita \\ de mamão mediante um sistema de embalagem antimicrobiana
}

\section{Autores | Authors}

Paula Judith Perez ESPITIA

Federal University of Viçosa (UFV) Food Technology Department Food Packaging Laboratory Viçosa/MG - Brazil e-mail: perez.espitia@gmail.com

\section{$\bowtie$ Nilda de Fátima Ferreira} SOARES

Federal University of Viçosa (UFV) Food Technology Department Food Packaging Laboratory CEP: 36570-000 Viçosa/MG - Brazil e-mail:nfsoares10@gmail.com

\section{Laura Costa Moreira BOTTI}

Federal University of Viçosa (UFV) Food Technology Department Food Packaging Laboratory Viçosa/MG - Brazil

e-mail: laura.alimentos@gmail.com

Nathália Ramos de MELO

Federal Fluminense University (UFF) Agribusiness Engineering Department Volta Redonda/RJ - Brazil

e-mail: nathaliarm@hotmail.com

\section{Olinto Liparini PEREIRA}

Federal University of Viçosa (UFV) Phytopathology Department Viçosa/MG - Brazil e-mail:oliparini@ufv.br

\section{Washington Azevêdo da SILVA}

Federal University of São João Del-Rei

Food Technology Department São João Del-Rei/MG - Brazil e-mail:wadasilva@hotmail.com

\ Autor Correspondente / Corresponding Author

Recebido / Received: 25/05/2011 Aprovado / Approved: 13/08/2012 Publicado / Published: dez./2012

\section{Summary}

Rot and damage caused by post-harvest phytopathogenic fungi affect fruit quality. Essential oils (EO) are considered as an alternative to fungicides. Postharvest diseases of fruits may also be controlled by the bagging approach and the use of antimicrobial packaging. Based on the beneficial properties of EO and the concepts of bagging and antimicrobial packaging, this study aimed to develop sachets containing $\mathrm{EO}$ to be used as part of an antimicrobial packaging system. The activities of oregano, cinnamon and lemon grass EO were evaluated testing the sachets in vitro against the phytopathogenic fungi Alternaria alternata, Fusarium semitectum, Lasiodiplodia theobromae and Rhizopus stolonifer. The effects of the sachets on the microbiological and physicochemical parameters of post-harvest papaya were also evaluated. Both pure and sachet-incorporated EO showed antifungal activity in vitro against all tested fungi. For papaya, sachets containing cinnamon, oregano and lemon grass showed a significant reduction in the growth of mesophilic aerobic bacteria, yeasts and mould, with the cinnamon sachet causing the greatest reduction in microorganisms at the end of the storage time. Physicochemical parameters of papaya, such as weight loss, colour, firmness, total soluble solids/titratable acidity ratio and $\mathrm{pH}$ were not significantly altered by the presence of EO sachets, thus not affecting the natural ripening process of the papaya.

Key words: Sachet; Essential oil; Antimicrobial packaging system; Microbial growth; Preservation; Antifungal activity; Physicochemical parameters.

\section{Resumo}

Podridão e danos pós-colheita causados por fungos fitopatogênicos afetam a qualidade das frutas. Óleos essenciais (OE) têm sido considerados como uma alternativa ao uso de fungicidas. Uma alternativa para o controle de doenças pós-colheita dos frutos é a técnica de ensacamento. Portanto, baseado nas propriedades benéficas dos OE e no conceito de ensacamento, este trabalho teve como objetivo desenvolver sachês incorporados com OE para serem usados como parte de um sistema de embalagem antimicrobiana. A atividade dos OE de orégano, canela e de capim-limão foi avaliada. Os sachês foram testados in vitro contra espécies de fungos fitopatogênicos de Alternaria alternata, Fusarium semitectum, Lasiodiplodia theobromae e Rhizopus stolonifer. Além disso, foram avaliados os efeitos dos sachês quanto aos parametros microbiológicos e físicoquímicos de mamão na pós-colheita. Os OE puros ou incorporados em sachê apresentaram atividade antifúngica in vitro contra todos os fungos testados. No acondicionamento de mamão, os sachês com canela, orégano e capim-limão mostraram uma redução significativa do crescimento de mesófilos aeróbicos e de bolores e leveduras, sendo o sachê com canela o de maior atividade na redução destes microrganismos após o tempo de estocagem. Os parâmetros físico-químicos de qualidade do mamão, como perda de peso, cor da casca, firmeza, relação sólidos solúveis totais/acidez titulável e pH não foram alterados significativamente pela presença dos sachês com OE, não afetando o processo natural de amadurecimento do mamão.

Palavras-chave: Sachê; Óleo essencial; Sistema de embalagem antimicrobiana; Crescimento microbiano; Preservação; Atividade antifúngica;

Parâmetros físico-químicos 


\section{Introduction}

The international trade of tropical fruit has increased in recent years due to consumer preference for experiencing different, exotic and diversified products (NUNES et al., 2006).

Papaya occupies a prominent place among the most important tropical fruits. According to the Food and Agriculture Organization, Brazil is one of the largest producers of papaya, producing 1,871,300 tons in 2010, second only to India which produced 4,713,800 tons that year (FAO, 2012). The importance of papaya for the economy of Brazil is demonstrated by its substantial production. However, postharvest diseases caused by fungi reduce the shelf life and market value of papaya.

Fungal colonization of food reduces its shelf life and market value, and makes it unfit for human consumption, in some cases due to mycotoxin production (KUMAR et al., 2008).

Among the available treatments to control fungal decay, hot water in combination with synthetic fungicides is generally used to reduce the incidence of postharvest diseases in various fruits and vegetables. However, heat treatments not only affect the nutritional quality but also the sensory properties, while the continuous use of synthetic fungicides may lead to the development of fungicide-resistant strains. Also, fungicide residues on the fruit surface constitute a serious risk to consumer health (MAQBOOL et al., 2011).

Moreover, in recent years many of the fungicides used in chemical treatments have been banned from the lists of officially allowed chemicals, due to the presence of residues in the fruit or the development of toxic metabolites, as well as being considered an environmental problem (CHITARRA and CHITARRA, 2005).

As a result, alternative strategies for the control of postharvest diseases have attracted the attention of scientists, and the use of essential oils and the bagging approach have been presented as alternatives to the use of fungicides.

Essential oils are natural substances, generally recognized as safe (GRAS) by the U.S. Food and Drug Administration (LÓPEZ et al., 2007). Their biological effects, including antibacterial and antifungal activity, as well as pharmaceutical and therapeutic potentials, have been well documented (BAKKALI et al., 2008; EDRIS, 2007).

Previous studies have shown that essential oils have antifungal activity both in vitro and when directly applied to the food (BARRERA-NECHA et al., 2008; GARCIA et al., 2008).

Although studies have shown the sustainable antimicrobial effect of essential oils in active packaging (RODRÍGUEZ et al., 2007; ROJAS-GRAÜ et al., 2007), the need remains for studies to show the successful application of essential oils as part of an active packaging system for the preservation of papaya fruit.

According to regulations 1935/2004/EC and $450 / 2009 / E C$ of the European Union, active packaging is defined as an active material with the ability to change the composition of the food or the atmosphere around it (RESTUCCIA et al., 2010). Moreover, antimicrobial packaging is a type of active packaging which interacts with the product or the head space inside to reduce, inhibit or retard the growth of microorganisms that may be present on food surfaces (SOARES et al., 2009).

Antimicrobial packaging that interacts with the head space consists of a packaging system using a sachet, which is a pad containing volatile antimicrobial agents, enclosed in the interior of the packaging or attached to it. Sachets within packages were the first example of commercial antimicrobial active packaging on the market and remain widely used (GONZÁLEZ-AGUILAR et al., 2010).

Another alternative for the control of postharvest disease in fruit is the bagging approach, which is generally used during development of the fruit to reduce disease and physical damage at harvest.

In addition to offering physical protection, the bagging approach also promotes changes in the microenvironment, which affects fruit quality (YANG et al., 2009). This approach has been widely practiced in the cultivation of peach, apple, mango, lychee, strawberry and grape, to produce high quality, unblemished fruit (JIA et al., 2005).

Therefore, based on the concepts of the bagging approach and the antimicrobial packaging system, as well as considering the beneficial effects of essential oils, the purpose of this study was to evaluate the antifungal activity of oregano, cinnamon and lemongrass essential oils incorporated in sachets, against different phytopathogenic fungal species in vitro. It also aimed to assess the activity of the sachets as part of an active packaging system with respect to microbial growth on the papaya, as well as to study the influence of the antimicrobial packaging system on the physical and chemical quality of the fruit.

\section{Material and methods}

\subsection{Essential oils}

Oregano (Origanum vulgare), cinnamon (Cinnamomum zeylanicum) or lemongrass (Cymbopogon flexuosus) essential oil was incorporated in the sachets as an antimicrobial agent. The essential oils were supplied by Petit Marie ${ }^{\circledR}$ (SP, Brazil) and their quality and stability were certified by the commercial supplier. 


\subsection{Microorganisms}

The Phytopathogenic fungi used in the in vitro experiments were Alternaria alternata, Fusarium semitectum, Lasiodiplodia theobromae and Rhizopus stolonifer, acquired from the culture collection of the Postharvest and Seed Pathology Laboratory at the Federal University of Viçosa, Brazil. Pure cultures were obtained directly by isolation from papaya fruits with postharvest rot symptoms. The cultures were used in the experiment at a concentration of $10^{4}$ spores. $\mathrm{mL}^{-1}$.

\subsection{Antifungal activity of essential oils}

The sensitivity of the phytopathogenic fungi to the pure essential oils was determined by the disk-diffusion method. Sterile filter paper disks, $10 \mathrm{~mm}$ in diameter (Whatman $\mathrm{N}^{\circ} 1$ ), were impregnated with $60 \mu \mathrm{L}$ of pure essential oil and placed in the centre of Petri dishes containing potato dextrose agar (Difco ${ }^{\mathrm{TM}}, \mathrm{NV}, \mathrm{USA}$ ) previously inoculated with $0.1 \mathrm{~mL}$ of a spore suspension of each fungus. The control treatment consisted of Petri dishes with sterile filter paper disks with no essential oil. The plates were sealed and incubated at $25^{\circ} \mathrm{C}$ for seven days. The activity of the essential oils was evaluated by the inhibition-halo diameter formed around the disk.

\subsection{Sachet development}

A high-absorption polymeric resin (Accurel $^{\circledR}, \mathrm{SP}$, Brazil) and nonwoven fabric were used to make the sachets and oregano, cinnamon or lemongrass essential oils were incorporated into individual sachets. The essential oils selected were added to the porous resin at concentrations of 10 and $20 \%(w / w)$. The resin was maintained in contact with the essential oils in glass containers hermetically sealed for 24 hours at $23 \pm 1{ }^{\circ} \mathrm{C}$ before elaborating the sachets. The resin was placed in sachets made of nonwoven fabric $\left(6 \times 7 \mathrm{~cm}^{2}\right)$ and heat sealed. The control sachets consisted of the same resin enclosed in a nonwoven fabric pad without the incorporation of any essential oil.

\subsection{In vitro activity of essential oil sachets}

Real conditions of sachet use were simulated, since the sachets are part of an antimicrobial packaging system and will have no direct contact with the fruit. Hence, the vapour phase method was used to determine the sensitivity of the phytopathogenic fungi to the essential oil sachets. Sachets from each treatment were placed individually on top of previously inoculated Petri dishes, with no direct contact between it and the microorganisms. The plates were sealed and incubated at $25 \pm 1{ }^{\circ} \mathrm{C}$ for seven days. The activity of the sachets was determined by measurement of the fungal mycelia that formed on each plate.

\subsection{Activity of essential oil sachets on papaya fruit}

Papaya fruit (Carica papaya L.) with a maturity stage of 2 (Table 1) obtained at the local market, were used in the experiments. The fruits were treated with a solution of sodium dichloroisocyanurate (Sumaveg ${ }^{\circledR}$, SP, Brazil) at a concentration of $200 \mathrm{mg}^{-\mathrm{L}^{-1}}$ (3\% active chlorine) for 10 minutes.

The sachet incorporated with $20 \%$ (w/w) of essential oil were selected for the application of the antimicrobial packaging system in papaya fruit. In natura papaya fruit were packaged in sealed paper pouches (42.10 g. $\mathrm{m}^{-2}$ and $0.072 \mathrm{~mm}$ of thickness) with an individual sachet with $20 \%(w / w)$ oregano, cinnamon or lemongrass essential oil, inside the pouch. The control treatment was a paper pouch with a sachet and no essential oil.

Packaged papayas were stored at $23 \pm 1{ }^{\circ} \mathrm{C}$, as in typical retail conditions, for 12 days. After $0,3,6,9$ and 12 days of storage, papaya fruits from each treatment were analyzed for the mesophilic aerobic bacterial count and the yeast and mould count, according to APHA (DOWNES and ITO, 2001).

\subsection{Determination of physical quality: weight loss, peel colour and firmness}

The masses of the individual papaya fruits were recorded on each day of analysis (0,3,6, 9 and 12). The cumulative weight losses were reported as the mean \pm standard deviation of papaya fruits from each

Table 1. Score range for papaya maturity according to the peel colour when stored at room temperature $\left(24 \pm 1^{\circ} \mathrm{C}, 75 \pm 5 \% \mathrm{RH}\right)$.

\section{Maturity stage}

0

1

2

3

4

5

\section{Description}

Completely developed fruit. $100 \%$ green skin colour.

Yellow colour does not cover more than $15 \%$ of the fruit surface.

$1 / 4$ mature. Fruit with up to $25 \%$ of the surface yellow, surrounded by a light green color.

$1 / 2$ mature. Fruit with up to $50 \%$ of the surface yellow, surrounded by a light green colour.

$3 / 4$ mature. Fruit with $50-75 \%$ of the surface yellow, surrounded by a light green colour.

Mature. Fruit with $76-100 \%$ of the surface yellow. Only the area near the stem is green.

Source: Export program for Brazilian papaya. Ministry of Agriculture, Livestock and Environment. 
treatment and expressed as a percentage loss of the original weight.

The peel colour was determined using the COLORQUEST ${ }^{\circledR}$ XE colorimeter (HunterLab, VA, USA). The individual $L^{*}, a^{*}$ and $b^{*}$ parameters were recorded and the results were given as the mean \pm standard deviation of five determinations made on the papaya fruit from each treatment in random positions. This analysis was done according to the CIELab colour scale, in which $L^{*}$ is a measurement of the brightness and varies from zero (black) to 100 (white), $a^{*}$ is positive $\left(+a^{*}\right)$ in the red direction and negative $\left(-a^{*}\right)$ in the green direction, and $b^{*}$ is positive $\left(+b^{*}\right)$ in the yellow direction and negative $\left(-b^{*}\right)$ in the blue direction.

Changes in the papaya fruit colour were quantified according to the chromaticity $\left(\mathrm{C}^{*}\right)$ and hue-angle index, as calculated from the $L^{*}, a^{*}$ and $b^{*}$ values using Equations 1 , 2 and 3 (LANCASTER et al., 1997).

$C^{*}=\left(a^{* 2}+b^{* 2}\right)^{0,5}$

oh $=\tan ^{-1}\left(b^{*} / a^{*}\right)$ when $a^{*}>0$ e $b^{*}>0$

oh $=180^{\circ}+\tan ^{-1}\left(b^{*} / a^{*}\right)$ when $a^{*}<0 e b^{*}>0$

The flesh firmness of the papaya pieces $(2 \times 3 \mathrm{~cm})$ was tested using the Universal Testing Machine (INSTRON 3367, IL, USA) in the compression mode with a $3 \mathrm{~mm}$ diameter probe. The pre-test speed, test speed and post-test speed were $5 \mathrm{~mm} . \mathrm{s}^{-1}, 1 \mathrm{~mm} . \mathrm{s}^{-1}$ and $10 \mathrm{~mm} . \mathrm{s}^{-1}$, respectively. The compression force was measured at the maximum peak of the recorded force and expressed in Newtons ( $N)$. The results were reported as the mean \pm standard deviation of each measurement made, using 10 pieces of papaya fruit from each treatment.

\subsection{Determination of chemical quality: TSS/TA ratio and $\mathrm{pH}$}

The total soluble solids (TSS) concentration, titratable acidity (TA) and TSS/TA ratio were determined in triplicate in triturated and homogenized papaya pulp (5 g) obtained from random areas with $30 \mathrm{~mL}$ of distilled water, according to AOAC (HOROWITZ, 1997). The results were expressed as the mean \pm standard deviation. The $\mathrm{pH}$ was measured in randomly sampled aliquots using a pH meter (Digimed DM 20, SP, Brazil).

\subsection{Statistical analysis}

The experiment was carried out 3 times in a completely randomized design and the results evaluated by an analysis of variance (ANOVA) at $5 \%$ probability. The statistical analysis was carried out using the Statistical Analysis System (SAS) version 9.1 (SAS Inc., Cary, N.C., U.S.A.).

\section{Results and discussion}

\subsection{Antifungal activity of pure essential oils}

Selected essential oils showed significant difference $(p<0.05)$ when compared with the control treatment, showing total inhibition of the phytopathogenic fungi tested: R. stolonifer, A. alternata, F. semitectum and $L$. Theobromae, with a mean inhibition zone of $85 \mathrm{~mm}$. Previous studies have shown the antimicrobial and antifungal activity of essential oils, but their mechanism of activity is still unknown (BAKKALI et al., 2008).

The activity of pure essential oils has been directly related to the action of volatiles such as phenolic compounds towards the fungi. Moreover, the extent of inhibition of the oils can be attributed to the presence of an aromatic nucleus containing a polar functional group, although other factors, such as the hydrophilic/lipophilic balance, are likely to be involved. Thus the phenolic-OH groups that are very reactive can easily form hydrogen bonds with the active sites of enzymes (GUYNOT et al., 2005).

Researchers have pointed out that the phenolic compounds in oregano essential oil, such as carvacrol, with predominance of about 74.56 to $81.46 \%$ of the total oil, are responsible for its activity (SOUZA et al., 2006). In cinnamon, the volatiles cinnamaldehyde, linalool, eugenol and cineol have been identified as the active compounds responsible for the inhibition of microbial growth. Similarly, lemongrass essential oil is characterized by a high citral content (66\%), a substance composed of isomeric neral $(37 \%)$ and geranial (29\%), and several studies have indicated this compound as being responsible for the activity of lemongrass essential oil (PAVIANI et al., 2006; TZORTZAKIS and ECONOMAKIS, 2007).

\subsection{In vitro activity of the essential oil sachets}

The results showed the complete inhibition of the phytopathogenic fungi in Petri dishes using both concentrations (10 and 20\%) of selected essential oil sachets (mean inhibition zone of $90 \mathrm{~mm}$ ). The essential oil sachets differed from the control, but there was no significant difference $(p>0.05)$ among the sachets with different essential oils.

The activity of essential oils is directly related to their volatile constituent (EDRIS, 2007). In this way, the porous resin used to develop the essential oil sachets was shown to be highly compatible with the essential oils, and allowed for the retention of their active constituents. The volatile compounds of the essential oils were absorbed by a carrier material (porous resin) and then released from the polymeric matrix into the headspace of the Petri dish to reach the inoculated agar surface.

Sachets are the most common way to incorporate active agents into packaging and are considered to be the most successful commercial application of antimicrobial 
agents (PEZO et al., 2007). Thus active packaging in the form of sachets is an attractive alternative for the control of fungal growth on fruit surfaces, since the volatile compound does not have to be in direct contact with the product. Moreover, it has been suggested that unwanted synthetic fungicides can be replaced by the incorporation of natural agents (such as essential oils) in an independent sachet (ALMENAR et al., 2009). Hence sachets containing the selected essential oils showed antifungal activity against all the microorganisms tested, indicating that this antimicrobial packaging form has the potential for use as part of an antimicrobial packaging system to control phytopathogenic fungi.

\subsection{Activity of essential oil sachets on papaya fruit}

The levels of essential oils and the necessary components required to inhibit microbial growth are higher in foods than in culture media, due to interactions between the phenolic compounds and the food matrix (TZORTZAKIS and ECONOMAKIS, 2007). Hence interactions between the essential oil and the food matrix should be considered in commercial applications.

Consequently, considering the possible interactions between papaya and the volatile compounds, sachets with $20 \%$ of essential oils were selected for use as part of the antimicrobial packaging system and to test their application in the postharvest preservation of papaya.

The microbial analyses of the papaya fruits in the antimicrobial packaging system showed significant differences in the mesophilic aerobic counts $(p<0.05)$ between the cinnamon essential oil treatment and the control on the $3^{\text {rd }}$ day of storage. Moreover, after the $9^{\text {th }}$ and $12^{\text {th }}$ days of storage all the essential oil sachets differed from the control regarding the mesophilic count. A significant difference $(p<0.05)$ in the results with time was also observed (Figure 1).

The control presented high mesophilic aerobic growth on the $6^{\text {th }}, 9^{\text {th }}$ and $12^{\text {th }}$ days of storage. In contrast, the treatment with cinnamon essential oil sachet presented the lowest value, with a reduction of 1.9 log cycles on the $6^{\text {th }}$ day and $2.2 \log$ cycles on the $9^{\text {th }}$ day, whereas on the $12^{\text {th }}$ day, cinnamon sachet only showed a reduction of $1.6 \log$ cycles.

The oregano and lemongrass sachets presented intermediary values for mesophilic aerobic growth on papaya on the $6^{\text {th }}$ and $9^{\text {th }}$ days. However, the oregano sachet presented a slight reduction in the counts for mesophilic aerobic growth (1.5 log cycle reduction) on the $12^{\text {th }}$ day.

These results for the microbiological quality of papaya fruit are in agreement with previous studies using the application of essential oils to fruits, either directly or by coating (FENG and ZHENG, 2007; ROJAS-GRAÜ et al., 2007). Papaya fruits, like many food products, are very sensitive to microbial attack, and this is worsened by the ripening process. Thus, the benefit achieved in the microbiological quality of papaya fruit should be attributed to the essential oil incorporated into the sachet, since the only difference between the control and the essential oil treatments was the presence of this antimicrobial agent.

The results obtained for the growth of mould and yeast on papaya fruit presented significant differences $(p<0.05)$ between the essential oil sachet treatments and the control. The greatest growth of these microorganisms in the control sample was observed on the $6^{\text {th }}$ and $9^{\text {th }}$ days of storage in relation to those submitted to the essential oil treatments (Figure 2).

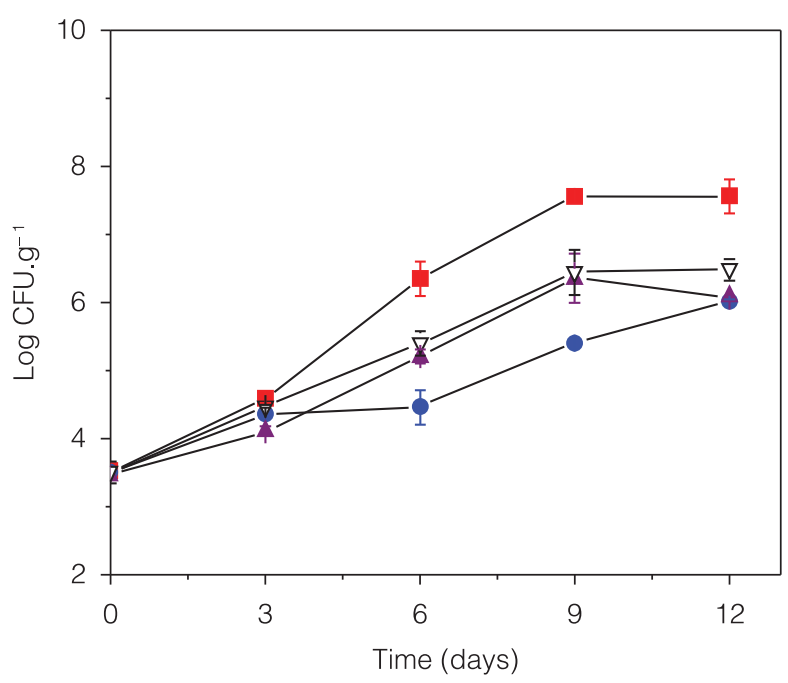

Figure 1. Growth of mesophilic aerobic microorganisms $\left(\log \mathrm{CFU} . \mathrm{g}^{-1}\right)$ in papaya for 12 days with sachets containing $20 \%$ oregano ( $\boldsymbol{\Delta}$ ), cinnamon $(\bullet)$ or lemongrass $(\nabla)$ essential oils incorporated and the control treatment ( $\boldsymbol{\square})$.

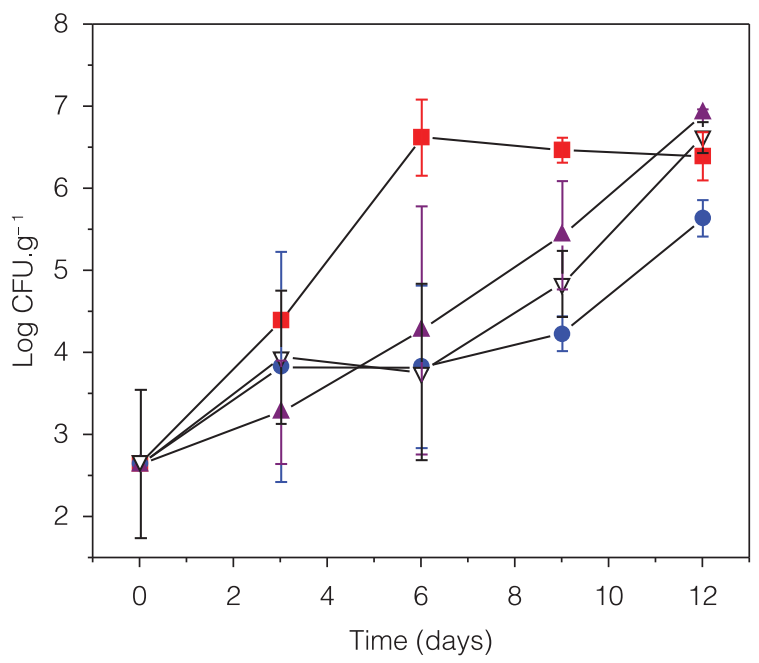

Figure 2. Growth of mould and yeast $\left(\log \mathrm{CFU} \cdot \mathrm{g}^{-1}\right)$ in papaya for 12 days with sachets containing $20 \%$ oregano ( $\Delta$ ), cinnamon ( ) or lemongrass $(\nabla)$ essential oil incorporated and the control treatment ( $\mathbf{\square})$. 
The treatments with cinnamon, oregano and lemongrass sachets presented significantly reduced values for the mould and yeast on the $6^{\text {th }}$ and $9^{\text {th }}$ days of storage. Moreover, on the last day of storage, the cinnamon sachet still maintained lower mould and yeast growth, whereas the oregano and lemongrass did not differ from the control.

These results are related to those obtained for the mesophilic aerobic microorganism, which showed that the cinnamon sachet presented the smallest count when compared with the control treatment. Thus, the cinnamon sachet was the treatment with the greatest microbial reduction in relation to the control.

Differences were observed between the in vitro and in vivo results in the antifungal efficacy tests, showing total inhibition of fungal growth in vitro and only partial reduction in the in vivo experiments. The effect of the antimicrobial activity of the essential oils in in vitro experiments is not the same as when tested in food. Higher concentrations of these compounds are usually necessary to achieve similar results when applied in in vivo experiments, due to interactions between phenolic compounds and the food matrix (FENG and ZHENG, 2007).

The complexity of the food matrix, a nutrientrich environment, allows microorganisms to reach their maximum replication rate and still have excess nutrients available for the repair or increased turnover of cellular components. As a result, the microorganism can be expected to exhibit increased resistance to many different stresses, which in this experiment is caused by the essential oil.

\subsection{Physical quality of the papaya fruit: weight loss, peel colour and firmness}

The weight loss of the papaya fruits showed no significant differences $(p>0.05)$ between the essential oil sachets and the control, indicating that the weight loss of the papaya was a result of the natural ripening process. Moreover, the average for this parameter presented a linear trend as a function of storage time for all the treatments (Figure 3).

The total weight of papaya fruit is constituted of about $90 \%$ of water. Weight loss is the major determinant of the storage life and quality of papaya fruit, and it is believed that the major pathway for water loss is through the peel (ALI et al., 2011). Weight loss in fruits is principally due to high storage temperatures, skin removal and cutting that exposes the interior tissues and drastically increases the water evaporation rate (RIVERA-LÓPEZ et al., 2005).

Peel colour is one of the principal visual attributes of papaya fruits and the colour changes continue during the storage period. In this experiment, the papaya fruit were initially characterized by a $25 \%$ yellow surface ( $1 / 4$ ripe), with the following colour coordinates on the first day of analysis: $56.22 \pm 3.38\left(L^{*}\right),-4.88 \pm 0.66\left(-a^{*}\right)$ and
$41.15 \pm 2.35\left(+b^{*}\right)$. During storage, the essential oil sachet treatments and the control showed variations in colour, with a reduction in the hue-angle values and increases in the chromaticity index (Figure 4), showing a maturity stage of 5 (Table 1) at the end of the storage time.

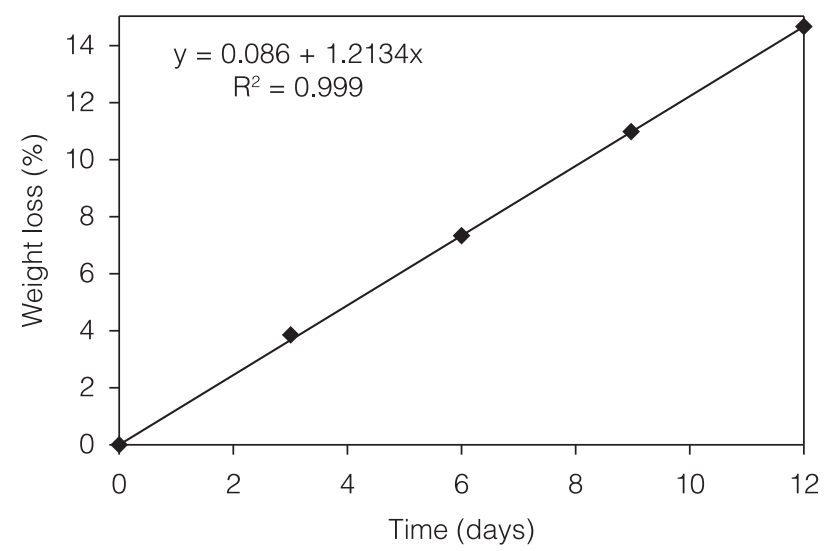

Figure 3. Average weight loss of the papaya fruit packaged in the antimicrobial packaging system during 12 days of storage.
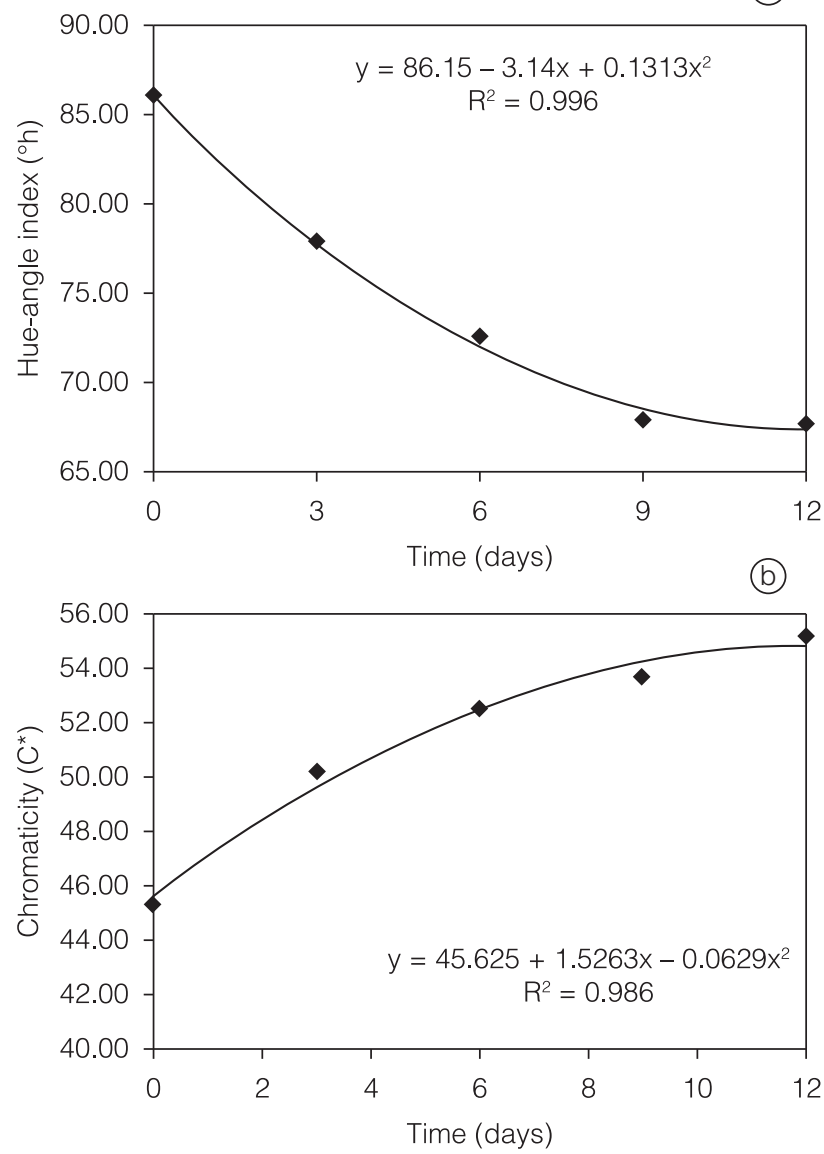

Figure 4. Average values for the Hue-angle index (a) and Chromaticity (b) of papaya fruit packaged in the antimicrobial packaging system during 12 days of storage. 

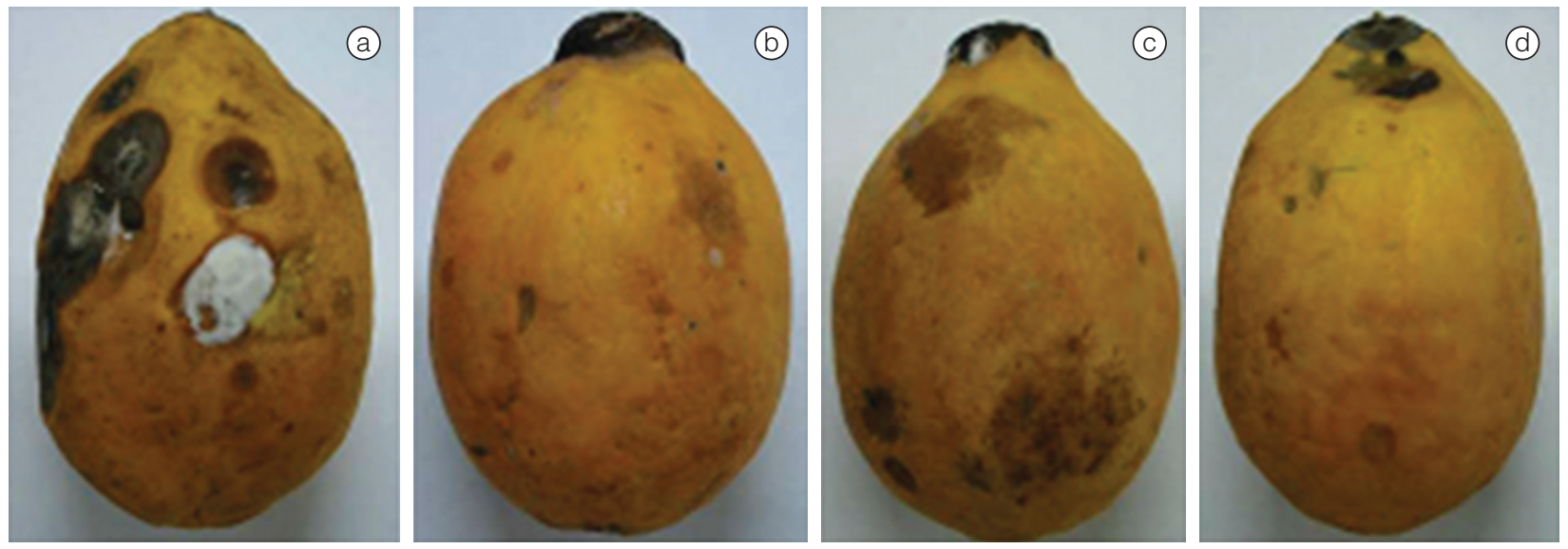

Figure 5. Appearance of the papaya fruit control (a) and papaya in antimicrobial packaging systems with oregano (b), cinnamon (c) and lemongrass (d) sachets, after 12 days of storage.

Also, at the end of the storage time the papaya fruits showed the appearance of random black spots on their surface, and the accelerated growth of fungi was visibly evident on the papaya fruits of the control treatment (Figure 5).

The results regarding the changes in the hue and chroma indices are in agreement with previous studies (HERNÁNDEZ et al., 2006; PEREIRA et al., 2009), related to changes in the skin colour of papaya during ripening. These studies indicated a natural change in the colour of papaya from green to yellow at the end of the storage time.

With respect to flesh firmness, a softening process occurred in both the control and the essential oil sachet treatments, with no significant difference $(p>0.05)$. The average value for the firmness of all the treatments at the beginning of the experiment was $15.65 \mathrm{~N}$, and this decreased to an average value of $2.44 \mathrm{~N}$ after 12 days of storage (Figure 6).

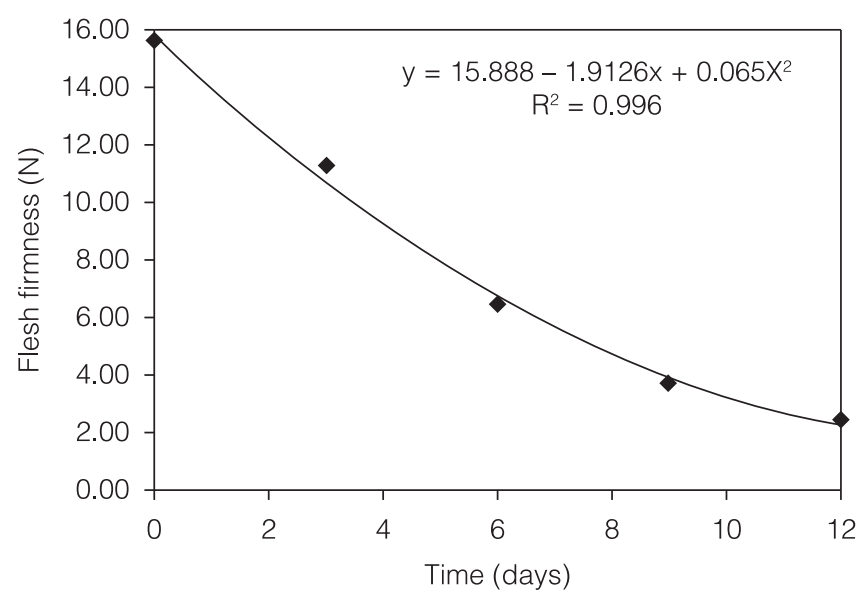

Figure 6. Average values for flesh firmness of papaya fruit packaged in antimicrobial packaging systems during 12 days of storage.
Papaya softening is due to deterioration of the cell wall structure as a result of a biochemical process involving the hydrolysis of pectin and the polysaccharide matrix by enzymes (MANENOI and PAULL, 2007). In this experiment the firmness of the papaya fruit changed throughout the storage time, but the presence of the sachets with oregano, cinnamon or lemongrass essential oil did not significantly affect this characteristic.

\subsection{Chemical quality of papaya fruit: TSS/TA ratio and $\mathrm{pH}$}

Sugars and organic acids are the major components that determine the taste and flavour of fruits. The TSS/TA ratio is the relationship between the soluble solids and titratable acidity, and is one of the commercially important parameters used to determine the maturity and quality of the fruit, since it represents the sweetness vs. the acidity of the fruit.

Results showed no significant difference $(p>0.05)$ between the TSS/TA ratios of papaya fruits packaged with the essential oil sachet treatments and that of the control. However, this ratio showed an increment throughout the storage time, with an initial value of 120.05 and a final value of 194.04 at the end of the storage time (Figure 7a). These values for the ratio indicated that while the TSS content increased with time, the acidity of papaya suffered a reduction during the storage time.

Similarly, the treatments with essential oil sachets did not differ significantly $(p>0.05)$ from the control regarding the $\mathrm{pH}$ measurement, although the $\mathrm{pH}$ values increased during the storage time as a result of the natural ripening process of the fruit (Figure $7 b$ ).

Results of this work are in agreement with those of previous studies (SANTOS, 2006), which showed an increase in the TSS of papaya fruits with time, indicating that the increase in TSS content was related to fruit 
(a)

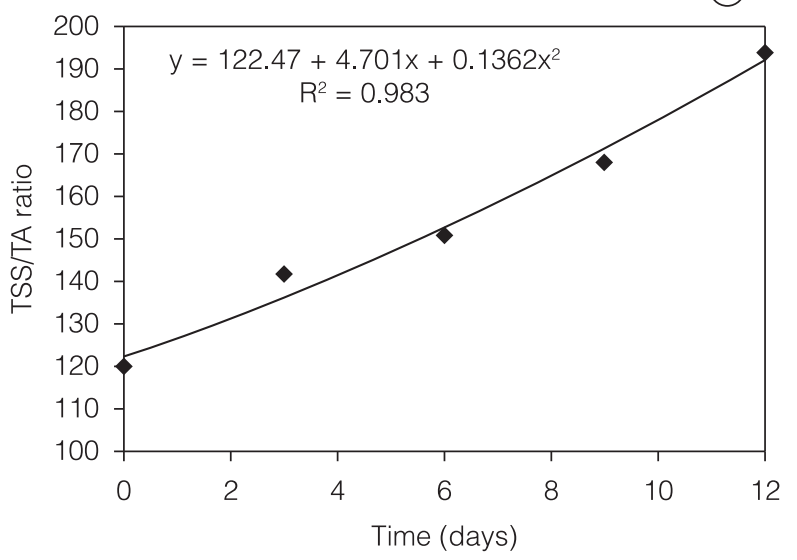

(b)

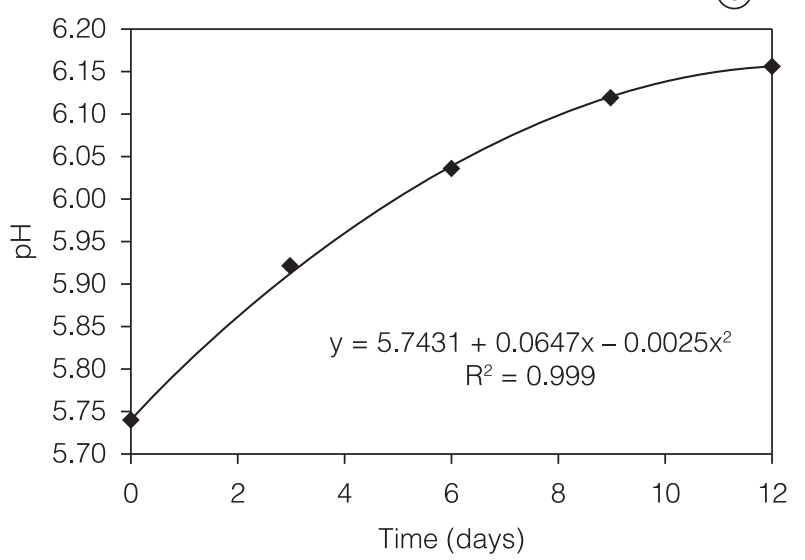

Figure 7. Average values for the TSS/TA ratio (a) and $\mathrm{pH}(\mathrm{b})$ of papaya fruit packaged in the antimicrobial packaging system during 12 days of storage.

ripening and therefore to yellowing of the papaya skin, and was also associated with reduced acidity of the pulp. Moreover, similar behaviour with respect to a reduction in acidity was also reported, indicating a gradual reduction in the percentage of citric acid in the pulp of papaya conditioned in different types of packaging, such as in bulk, in wooden boxes, in wavy cardboard boxes and in plastic boxes with bubble wrap.

This reduction in the acidity levels during storage is probably due to the increased metabolism of the fruit, resulting in a greater consumption of organic acids in the respiratory process. Hence, although the titratable acidity did not present significant changes at the beginning of ripening, these values tended to decline slowly up to the end of maturation.

\section{Conclusion}

The essential oil sachet was used as part of an antimicrobial packaging system for the postharvest preservation of papaya fruit and showed inhibition of phytopathogenic fungi in vitro, as well as a reduction in microbial growth in papaya fruit. Also, the sachets showed no adverse effects on the quality of the papaya fruit treated, since significant differences between those used in the essential oil sachet treatments and the control samples were not observed for the physical and chemical quality parameters with storage time. This indicated that the natural ripening process was not affected by the presence of the essential oil sachets. Therefore, the use of sachets with the incorporation of oregano, cinnamon or lemongrass essential oils shows promise in the control of postharvest diseases in papaya, with minimum alterations to the ripening process of the fruit.

\section{Acknowledgements}

The authors would like to thank Mr. Nicholas J. Walker for providing assistance with the language and writing. They also gratefully acknowledge the Conselho Nacional de Desenvolvimento Científico e Tecnológico (CNPq) and the Coordenação de Aperfeiçoamento de Pessoal de Nivel Superior (CAPES) for providing financial support.

\section{References}

ALI, A.; MUHAMMAD, M. T. M.; SIJAM, K.; SIDDIQUI, Y. Effect of chitosan coatings on the physicochemical characteristics of Eksotika II papaya (Carica papaya L.) fruit during cold storage. Food Chemistry, London, v. 124, n. 2, p. 620-626, 2011. http:// dx.doi.org/10.1016/j.foodchem.2010.06.085

ALMENAR, E.; CATALA, R.; HERNANDEZ-MUÑOZ, P.; GAVARA, R. Optimization of an active package for wild strawberries based on the release of 2-nonanone. LWT - Food Science and Technology, Amsterdam, v. 42, n. 2, p. 587-593, 2009. http:// dx.doi.org/10.1016/j.Iwt.2008.09.009

BAKKALI, F.; AVERBECK, S.; AVERBECK, D.; IDAOMAR, M. Biological effects of essential oils - A review. Food and Chemical Toxicology, Amsterdam, v. 46, n. 2, p. 446-475, 2008. http:// dx.doi.org/10.1016/j.fct.2007.09.106

BARRERA-NECHA, L. L.; BAUTISTA-BAÑOS, S.; FLORESMOCTEZUMA, H. E.; ESTUDILLO, A. R. Efficacy of essential oils on the conidial germination, growth of Colletotrichum gloeosporioides (Penz.) penz. and sacc and control of postharvest diseases in papaya (Carica papaya L.). Plant Pathology Journal, New York, v. 7, n. 2, p. 174-178, 2008. http:// dx.doi.org/10.3923/ppj.2008.174.178

CHITARRA, M. I. F.; CHITARRA, A. B. Pós-colheita de Frutas e Hortaliças: Fisiologia e Manuseio. Lavras: UFLA Editorial, 2005. 785 p.

DOWNES, F. P.; ITO, K. Compendium of Methods for the Microbiological Examination of Foods. 4th ed. Washington: American Public Health Association, 2001. 677 p.

EDRIS, A. E. Pharmaceutical and therapeutic Potentials of essential oils and their individual volatile constituents: a review. 
Assessment of the efficiency of essential oils in the preservation of postharvest papaya in an antimicrobial packaging system

ESPITIA, P. J. P. et al.

Phytotherapy Research, Malden, v. 21, n. 4, p. 308-323, 2007. http://dx.doi.org/10.1002/ptr.2072

FENG, W.; ZHENG, X. Essential oils to control Alternaria alternata in vitro and in vivo. Food Control, Amsterdam, v. 18, n. 9, p. 1126-1130, 2007. http://dx.doi.org/10.1016/j. foodcont.2006.05.017

FOOD AND AGRICULTURE ORGANIZATION OF THE UNITED NATIONS - FAO. Statistical Databases. FAO, 2012. Disponível em: <http://faostat.fao.org/site/567/DesktopDefault. aspx?PagelD=567\#ancor $>$. Acesso em: 13 jun. 2012.

GARCIA, R.; ALVES, E. S. S.; SANTOS, M. P.; AQUIJE, G. M. F. V.; FERNANDES, A. A. R.; SANTOS, R. B. D.; VENTURA, J. A.; FERNANDES, P. M. B. Antimicrobial activity and potential use of monoterpenes as tropical fruits preservatives. Brazilian Journal of Microbiology, São Paulo, v. 39, p. 163-168, 2008. http://dx.doi.org/10.1590/S1517-83822008000100032

GONZÁLEZ-AGUILAR, G.; AYALA-ZAVALA, J.; OLIVAS, G.; DE LA ROSA, L.; ÁLVAREZ-PARRILLA, E. Preserving quality of fresh-cut products using safe technologies. Journal für Verbraucherschutz und Lebensmittelsicherheit, Basel, v. 5, n. 1, p. 65-72, 2010. http://dx.doi.org/10.1007/s00003-0090315-6

GUYNOT, M. E.; MARÍN, S.; SETÚ, L.; SANCHIS, V.; RAMOS, A. J. Screening for antifungal activity of some essential oils against common spoilage fungi of bakery products. Food Science and Technology International, London, v. 11, n. 1, p. 25-32, 2005. http://dx.doi.org/10.1177/1082013205050901

HERNÁNDEZ, Y.; LOBO, M. G.; GONZÁLEZ, M. Determination of vitamin $C$ in tropical fruits: A comparative evaluation of methods. Food Chemistry, London, v. 96, n. 4, p. 654-664, 2006. http:// dx.doi.org/10.1016/j.foodchem.2005.04.012

HOROWITZ, W. Official methods of analysis of the Association of Official Analytical Chemists. 16th ed. Washington: Association of Official Analytical Chemists, 1997. $1 \mathrm{v}$.

JIA, H.-J.; ARAKI, A.; OKAMOTO, G. Influence of fruit bagging on aroma volatiles and skin coloration of 'Hakuho' peach (Prunus persica Batsch). Postharvest Biology and Technology, Amsterdam, v. 35, n. 1, p. 61-68, 2005. http:// dx.doi.org/10.1016/j.postharvbio.2004.06.004

KUMAR, A.; SHUKLA, R.; SINGH, P.; PRASAD, C. S.; DUBEY, N. K. Assessment of Thymus vulgaris L. essential oil as a safe botanical preservative against post harvest fungal infestation of food commodities. Innovative Food Science \& Emerging Technologies, Amsterdam, v. 9, n. 4, p. 575-580, 2008. http:// dx.doi.org/10.1016/j.ifset.2007.12.005

LANCASTER, J. E.; LISTER, C. E.; REAY, P. F.; TRIGGS, C. M. Influence of pigment composition on skin color in a wide range of fruit and vegetables. Journal of the American Society for Horticultural Science, Alexandria, v. 122, n. 4, p. 594-598, 1997.
LÓPEZ, P.; SÁNCHEZ, C.; BATLLE, R.; NERÍN, C. Development of flexible antimicrobial films using essential oils as active agents. Journal of Agricultural and Food Chemistry, Washington, v. 55 , n. 21 , p. $8814-8824,2007$. http://dx.doi.org/10.1021/ jf071737b

MANENOI, A.; PAULL, R. E. Papaya fruit softening, endoxylanase gene expression, protein and activity. Physiologia Plantarum, Malden, v. 131, n. 3, p. 470-480, 2007. http://dx.doi.org/10.1111/ j.1399-3054.2007.00967.x

MAQBOOL, M.; ALI, A.; ALDERSON, P. G.; MOHAMED, M. T. M.; SIDDIQUI, Y.; ZAHID, N. Postharvest application of gum arabic and essential oils for controlling anthracnose and quality of banana and papaya during cold storage. Postharvest Biology and Technology, Amsterdam, v. 62, n. 1, p. 71-76, 2011. http:// dx.doi.org/10.1016/j.postharvbio.2011.04.002

NUNES, M. C. N.; EMOND, J. P.; BRECHT, J. K. Brief deviations from set point temperatures during normal airport handling operations negatively affect the quality of papaya (Carica papaya) fruit. Postharvest Biology and Technology Amsterdam, v. 41, n. 3, p. 328-340, 2006. http://dx.doi. org/10.1016/j.postharvbio.2006.04.013

PAVIANI, L.; PERGHER, S. B. C.; DARIVA, C. Application of molecular sieves in the fractionation of lemongrass oil from high-pressure carbon dioxide extraction. Brazilian Journal of Chemical Engineering, São Paulo, v. 23, p. 219-225, 2006. http://dx.doi.org/10.1590/S0104-66322006000200009

PEREIRA, T.; DE ALMEIDA, P. S. G.; DE AZEVEDO, I. G.; DA CUNHA, M.; DE OLIVEIRA, J. G.; DA SILVA, M. G.; VARGAS, $H$. Gas diffusion in 'Golden' papaya fruit at different maturity stages. Postharvest Biology and Technology, Amsterdam, v. 54, n. 3, p. 123-130, 2009. http://dx.doi.org/10.1016/j. postharvbio.2009.07.010

PEZO, D.; SALAFRANCA, J.; NERÍN, C. Development of an automatic multiple dynamic hollow fibre liquid-phase microextraction procedure for specific migration analysis of new active food packagings containing essential oils. Journal of Chromatography A, Amsterdam, v. 1174, n. 1-2, p. 85-94, 2007. http://dx.doi.org/10.1016/j.chroma.2007.08.033

RESTUCCIA, D.; SPIZZIRRI, U. G.; PARISI, O. I.; CIRILLO, G.; CURCIO, M.; IEMMA, F.; PUOCI, F.; VINCI, G.; PICCI, N. New EU regulation aspects and global market of active and intelligent packaging for food industry applications. Food Control, Amsterdam, v. 21, n. 11, p. 1425-1435, 2010. http:// dx.doi.org/10.1016/j.foodcont.2010.04.028

RIVERA-LÓPEZ, J.; VÁZQUEZ-ORTIZ, F. A.; AYALA-ZAVALA, J. F.; SOTELO-MUNDO, R. R.; GONZÁLEZ-AGUILAR, G. A. Cutting shape and storage temperature affect overall quality of fresh-cut papaya cv. 'Maradol'. Journal of Food Science, Malden, v. 70, n. 7, p. s482-s489, 2005. http://dx.doi. org/10.1111/j.1365-2621.2005.tb11496.x

RODRÍGUEZ, A.; BATLLE, R.; NERÍN, C. The use of natural essential oils as antimicrobial solutions in paper packaging. 
Assessment of the efficiency of essential oils in the preservation of postharvest papaya in an antimicrobial packaging system

ESPITIA, P. J. P. et al.

Part II. Progress in Organic Coatings, Amsterdam, v. 60, n. 1, p. 33-38, 2007. http://dx.doi.org/10.1016/j.porgcoat.2007.06.006

ROJAS-GRAÜ, M. A.; RAYBAUDI-MASSILIA, R. M.; SOLIVAFORTUNY, R. C.; AVENA-BUSTILLOS, R. J.; McHUGH, T. H.; MARTÍN-BELLOSO, O. Apple puree-alginate edible coating as carrier of antimicrobial agents to prolong shelf-life of fresh-cut apples. Postharvest Biology and Technology, Amsterdam, v. 45, n. 2, p. 254-264, 2007. http://dx.doi.org/10.1016/j. postharvbio.2007.01.017

SANTOS, C. E. M. Qualidade pós-colheita do mamão Formosa “Tainung 01" influenciada pelo tipo de embalagem usada no transporte rodoviário. 2006. 54 f. Dissertação (Mestrado em Fitotecnia)-Faculdade de Fitotecnia, Universidade Federal de Viçosa, Viçosa.

SOARES, N. F. F.; PIRES, A. C. S.; CAMILLOTO, G. P.; SANTIAGOSILVA, P.; ESPITIA, P. J. P.; SILVA, W. A. Recent patents on active packaging for food application. Recent Patents on Food, Nutrition \& Agriculture, Sharjah, v. 1, n. 1, p. 171-178, 2009.

SOUZA, E. L. D.; STAMFORD, T. L. M.; LIMA, E. D. O. Sensitivity of spoiling and pathogen food-related bacteria to Origanum vulgare L. (Lamiaceae) essential oil. Brazilian Journal of Microbiology, São Paulo, v. 37, p. 527-532, 2006. http://dx.doi. org/10.1590/S1517-83822006000400023

TZORTZAKIS, N. G.; ECONOMAKIS, C. D. Antifungal activity of lemongrass (Cympopogon citratus L.) essential oil against key postharvest pathogens. Innovative Food Science and Emerging Technologies, Amsterdam, v. 8, n. 2, p. 253-258, 2007. http:// dx.doi.org/10.1016/j.ifset.2007.01.002

YANG, W.-H.; ZHU, X.-C.; BU, J.-H.; HU, G.-B.; WANG, H.-C.; HUANG, X.-M. Effects of bagging on fruit development and quality in cross-winter off-season longan. Scientia Horticulturae, Amsterdam, v. 120, n. 2, p. 194-200, 2009. http:// dx.doi.org/10.1016/j.scienta.2008.10.009 